Matgorzata Bajgier-Kowalska

Krakowska Akademia im. A.F. Modrzewskiego, Kraków, Polska

RENATA RETTINGER

Uniwersytet Pedagogiczny, Kraków, Polska

\title{
Kierunki przemian regionów turystyki wypoczynkowej w warunkach kryzysu gospodarczego na przykładzie Algarve w Portugalii
}

\section{Trends in leisure tourism regions under economic crisis conditions based on the example of Algarve in Portugal}

\begin{abstract}
Streszczenie: Algarve jest regionem turystyki wypoczynkowej charakteryzującym się bardzo dobrą infrastrukturą turystyczną i dostępnością komunikacyjną (lotniczą i samochodową). To jeden z najważniejszych regionów wypoczynkowych Portugalii oraz miejsce wypoczynku dla obywateli Niemiec i Wielkiej Brytanii. Bliskie sąsiedztwo Hiszpanii sprawia, że regiony te konkurują ze sobą o klientów w warunkach zmieniającej się koniunktury gospodarczej. Głównym celem opracowania jest analiza wpływu kryzysu gospodarczego na wielkość ruchu turystycznego w południowej części Portugalii oraz próba oceny działań prowadzących do zmniejszenia bądź wyeliminowania negatywnych skutków. W artykule przedstawiono szereg rozwiązań instytucjonalnych zmierzających do zwiększenia ruchu turystycznego, np. poprzez zmniejszenie zjawiska sezonowości oraz innowacje produktowe i procesowe, które w zasadniczy sposób mogą obniżyć koszty funkcjonowania podmiotów gospodarczych branży turystycznej.
\end{abstract}

Abstract: Abstract The phenomenon of spatial concentration of tourist activity leads directly to the
emerging of tourist regions understood as spatial units with a dominant function of tourism. The af-
termath of a crisis is most visible in the areas of tourist reception and take the form of a decreased
tourist activity, which leads to lower income of companies working in the tourist industry. Algarve is
a region of leisure tourism characterized by a well-developed tourism infrastructure and transportation
availability (by air and land). The area is one of the biggest leisure regions of Portugal and a holiday
destination for citizens of countries such as Germany or the UK. The vicinity of Spain causes the two
countries to compete for their clients in the conditions of changing economical trends. The main goal
of this case study is the analysis of the influence of the economic crisis on the volume of tourist activity 
in the Northern part of Portugal and the attempt at evaluating actions taken to decrease or eliminate the results of that crisis. The article presents a variety of organizational solutions aiming at increasing the tourist activity. Examples of such actions include reducing seasonal fluctuations or product and process innovation which could considerably lower the costs of running a tourism-focused company. One of the possible ways of limiting the results of world crisis is diversifying the tourist product basing on the existing tourist potential. This may result in the growth of tourist activity, due to attracting new clients.

Slowa kluczowe: Algarve; Portugalia; produkt turystyczny

Keywords: Algarve; Portugal; tourist product

\section{WSTĘP}

Rozwój i kształtowanie się międzynarodowego rynku turystycznego są uwarunkowane wieloma czynnikami, mającymi zróżnicowany charakter. Do grupy tzw. czynników zewnętrznych zaliczamy zmieniające się otoczenie społeczne, gospodarcze i polityczne, natomiast do wewnętrznych należą elementy infrastruktury turystycznej i usług turystycznych oraz czynniki kształtujące wielkość i strukturę podaży turystycznej. Mogą one działać stymulująco lub hamująco na kierunki rozwoju turystyki w istniejących bądź powstających obszarach recepcji turystycznej. Sytuacje takie jak kryzys gospodarczy powodują globalnie zmniejszenie wielkości ruchu turystycznego na świecie (Zdon-Korzeniowska, Rachwał, 2011), ale nie dotyczy to wszystkich regionów i nie wszędzie występuje w takiej samej skali. Dlatego też należy postawić pytanie: jak sobie radzą z kryzysem poszczególne typy regionów turystycznych? Czy ma znaczenie wielkość, typ regionu, jego położenie geograficzne, a w konsekwencji charakter proponowanego produktu turystycznego?

Relacje pomiędzy turystyką a pozostałymi branżami światowej gospodarki są tematem wielu opracowań naukowych, dotyczących wzajemnych powiązań funkcjonalnych i przestrzennych. Są one analizowane na kilku płaszczyznach i w różnych skalach przestrzennych (globalnych, regionalnych i lokalnych). Zagadnienie wpływu turystyki na rozwój gospodarczy znalazło szerokie odbicie w literaturze naukowej, zwłaszcza XXI wieku. Wcześniejsze badania koncentrowały się wyraźnie na ukazaniu wpływu turystyki na rozwój gospodarczy krajów rozwijających się (m.in. Bryden, 1973; Heng, Low, 1990; Archer, 1995), pokazaniu korzyści dla gospodarki w wyniku powstawania dochodów podatkowych, tworzenia miejsc pracy i generowania dodatkowych przychodów (Belisle, Hoy, 1980; Davis i in., 1988; Khan i in., 1990; Archer, 1995; Durbarry, 2002).

Istotne miejsce w tych badaniach zajmują wzajemne relacje między turystyką międzynarodową i handlem (m.in. Gray, 1970; Keintz, 1971). Najnowsze publikacje potwierdzają również te zależności (Kadir, Jusoff, 2010; Santana-Gallego i in., 2011; Lionetti, Gonzalez 2012). Analiza związku między turystyką a wzrostem gospodarczym jest obecnie tematem wielu badań empirycznych i publikacji naukowych (m.in. Brida, Risso, 2009; Cortés-Jimenez i in., 2011; Brida i in., 2011; Dritsakis, 2012; Ekanayake, Long, 2012). Kompleksowa analiza tych prac została przeprowadzona przez Pablo-Romero i Molinę (2013). Przyjmuje się, że jeżeli wpływ turystyki na gospodarkę jest duży, to jej rozwój będzie bezpośrednio wpływał 
na inne sektory z nią związane, a tym samym na całą gospodarkę, w konsekwencji wytwarzając wzrost ekonomiczny. Jednak wielkość tego efektu różni się znacznie, nie tylko między badanymi państwami, ale także ze względu na przyjętą metodologię badań.

Jednocześnie należy podkreślić, sygnalizowaną w literaturze, czułość turystyki na sytuację makroekonomiczną na świecie, niekorzystne zjawiska meteorologiczne lub niestabilność polityczną (Algieri, 2006; Narayan i in., 2010). W światowej gospodarce, zdeterminowanej przez procesy o charakterze globalnym, zewnętrzne uwarunkowania rozwoju regionu są istotnym impulsem zmian i dostosowań wewnętrznych, co może sprzyjać tworzeniu pozycji konkurencyjnej regionów (Chądzyński i in., 2012). W latach 2008-2010 szczególnego znaczenia w przemianach sektora turystycznego nabrał światowy kryzys gospodarczy oraz związane z nim działania rządów różnych krajów, podejmowane w celu przeciwdziałania jego skutkom, a także upadek wielu firm, w tym transportowych, i instytucji finansowych ściśle związanych z sektorem turystycznym: banków, towarzystw ubezpieczeniowych (Zdon-Korzeniowska, Rachwał, 2011).

Zjawisko koncentracji przestrzennej ruchu turystycznego prowadzi bezpośrednio do wyodrębniania się regionów czy też ośrodków turystycznych jako jednostek przestrzennych z dominującą funkcją turystyczną. Skutki kryzysu są najbardziej widoczne w obszarach recepcji turystycznej poprzez zmniejszenie wielkości ruchu turystycznego, co w konsekwencji skutkuje mniejszymi wpływami wytwarzanymi przez podmioty gospodarcze działające w branży turystycznej. Światowy kryzys gospodarczy, który w pełni uwidocznił się w drugiej połowie 2008 roku, był odczuwalny w mniejszym lub większym stopniu w każdej branży gospodarki.

Według danych WTTC (World Travel \& Tourism Council) ogólna liczba międzynarodowych przyjazdów w skali świata w 2009 roku wynosiła ponad 1,6 mld osób i była o ponad 5,3\% niższa w porównaniu z rokiem 2008. Podobnie spadek o ponad 5\% zanotowano w 2009 roku w odniesieniu do liczby przyjeżdżających turystów zagranicznych (pobyty powyżej 24 godzin) w skali świata w porównaniu z rokiem poprzednim. Natomiast już w 2010 roku ruch w turystyce międzynarodowej wzrósł o $6,7 \%$ w porównaniu z rokiem 2009, choć przewidywania były na poziomie 5-6\%. Według Światowej Organizacji Turystyki (UNWTO, United Nations World Tourism Organization) w 2010 roku z wyjazdów turystycznych skorzystało ok. 935 mln osób, a wzrost liczby odwiedzających odnotowano we wszystkich regionach na świecie.

Po światowym kryzysie gospodarczym i recesji z lat 2008-2009 światowa turystyka nie tylko powróciła do wcześniejszego stanu, ale nawet przekroczyła poziom sprzed kryzysu. W pierwszej połowie 2013 roku liczba międzynarodowych podróży turystycznych wzrosła w porównaniu z rokiem poprzednim o ok. $25 \mathrm{mln}$ - do $494 \mathrm{mln}$. Ten wzrost o $5 \%$ to wynik znacznie lepszy niż prognozowali eksperci UNWTO na początku roku, szacując, że wyniesie on 3-4\%. Z kolei długoterminowa prognoza zakłada, że do 2020 roku średni wzrost ruchu turystycznego będzie na poziomie 3,8\% rocznie. Odwrócenie niekorzystnych trendów odnotowuje się również w zakresie innych wskaźników, takich jak popyt turystyczny, udział gospodarki i przemysłu turystycznego w PKB oraz tworzenie nowych miejsc pracy (Zdon-Korzeniowska, Rachwał, 2011). Ciągły wzrost liczby podróżnych świadczy o roli turystyki w światowej gospodarce w pobudzaniu wzrostu gospodarczego wielu krajów. 


\section{PortUGALIA JAKO REGION TURYSTYCZNY}

Atrakcyjność turystyczna Portugalii jest uwarunkowana przede wszystkim jej bogactwem naturalnym, reprezentowanym przez różnorodne krajobrazy, piękne, czyste plaże, sprzyjający wypoczynkowi klimat, a także bogactwem kulturowo-historycznym, będącym świadectwem potęgi byłego imperium kolonialnego. Baza noclegowa, gastronomiczna i cała infrastruktura towarzysząca jest na najwyższym europejskim poziomie, a ceny są zdecydowanie bardziej atrakcyjne niż np. w pobliskiej Hiszpanii.

Portugalia jest jednym z ważniejszych regionów turystycznych Europy. W 2011 roku odwiedziło ją prawie $14 \mathrm{mln}$ turystów zagranicznych, pochodzących przede wszystkim z Wielkiej Brytanii, Niemiec, Hiszpanii, Francji i Holandii (ryc. 1). Nie można też zapominać o wielkości ruchu krajowego, który jest mniejszy od zagranicznego o zaledwie 556 tys. turystów. Portugalia jest przykładem kraju, w którym występuje obecnie równowaga pomiędzy wielkością zagranicznego i krajowego ruchu turystycznego. W ciągu ostatnich 20 lat liczba turystów zagranicznych podwoiła się i cały czas utrzymuje się trend rosnący, z wyjątkiem roku 2009. Kryzysowy rok skutkował spadkiem liczby turystów zagranicznych (o około 600 tys.) i wzrostem liczby turystów krajowych (ryc. 1). Największe spadki dotyczyły turystów z Wielkiej Brytanii (o 164 tys.) i tendencja ta utrzymywała się przez 2 lata. W przypadku turystów z innych krajów spadki były mniejsze i trwały tylko rok.

Tab. 1. Wielkość zagranicznego ruchu turystycznego w Portugalii w latach 1990-2011

\begin{tabular}{|c|c|c|c|}
\hline Lata & $\begin{array}{c}\text { Liczba turystów } \\
\text { zagranicznych }\end{array}$ & $\begin{array}{c}\text { Liczba udzielonych } \\
\text { noclegów }\end{array}$ & $\begin{array}{c}\text { Średnia długość pobytu } \\
\text { turystów zagranicznych }\end{array}$ \\
\hline 1990 & 7330276 & 23813534 & 4,1 \\
\hline 1995 & 8020570 & 27936842 & 4,5 \\
\hline 2000 & 10317217 & 33795123 & 4,2 \\
\hline 2005 & 11469314 & 35520631 & 4,0 \\
\hline 2006 & 12376941 & 37566461 & 3,9 \\
\hline 2007 & 13366173 & 39736583 & 3,8 \\
\hline 2008 & 13456372 & 39227938 & 3,7 \\
\hline 2009 & 12927907 & 36457069 & 3,6 \\
\hline 2010 & 13537040 & 37391291 & 3,5 \\
\hline 2011 & 13992782 & 39440315 & 3,5 \\
\hline
\end{tabular}

Żródło: Anuário Estatístico de Portugal 2011, Instituto Nacional de Estatística, IP

Turystyka dostarcza prawie 10\% PKB Portugalii, jest jednym z głównych sektorów gospodarczych, a także miejsc pracy. Posiada ona 14\% udziałów w wartości sprzedaży zagranicznej Portugalii, a także koncentruje 8\% osób pracujących w tym kraju. W 2011 roku sektor ten zanotował wzrost obrotów o 8,7\% w porównaniu z 2010 rokiem, a liczba gości hotelowych zwiększyła się o 5\%. W 2012 roku portugalskie hotele miały obroty na poziomie 
ok. 480 mln euro, czyli o 6\% mniej niż w 2011 roku. Od stycznia do czerwca 2013 roku wpływy portugalskiego sektora turystycznego przekroczyły kwotę 3,7 mld euro, co oznacza wzrost o 8,2\% w porównaniu z analogicznym okresem w 2012 roku (Anuário Estatístico de Portugal 2011, 2012). Większość z nich została wytworzona w regionie Algarve oraz w Lizbonie.

Wśród narodowości, które wyraźnie zwiększyły swoje wyjazdy turystyczne do Portugalii oraz wydatki w tym kraju, są Amerykanie. Wg szacunków Krajowego Instytutu Statystycznego w Lizbonie (INE), w pierwszej połowie 2013 roku Amerykanie wydali w Portugalii podczas urlopów rekordową kwotę 227 mln euro. W analogicznym okresie 2012 roku ich wydatki były tam mniejsze o 27\%. Obok Amerykanów wśród najczęściej spędzających urlop w Portugalii są nadal Niemcy, Brytyjczycy, Holendrzy oraz Irlandczycy (ryc. 1). Turyści z Polski zajmują 11 miejsce wśród narodów najliczniej odwiedzających Portugalię.

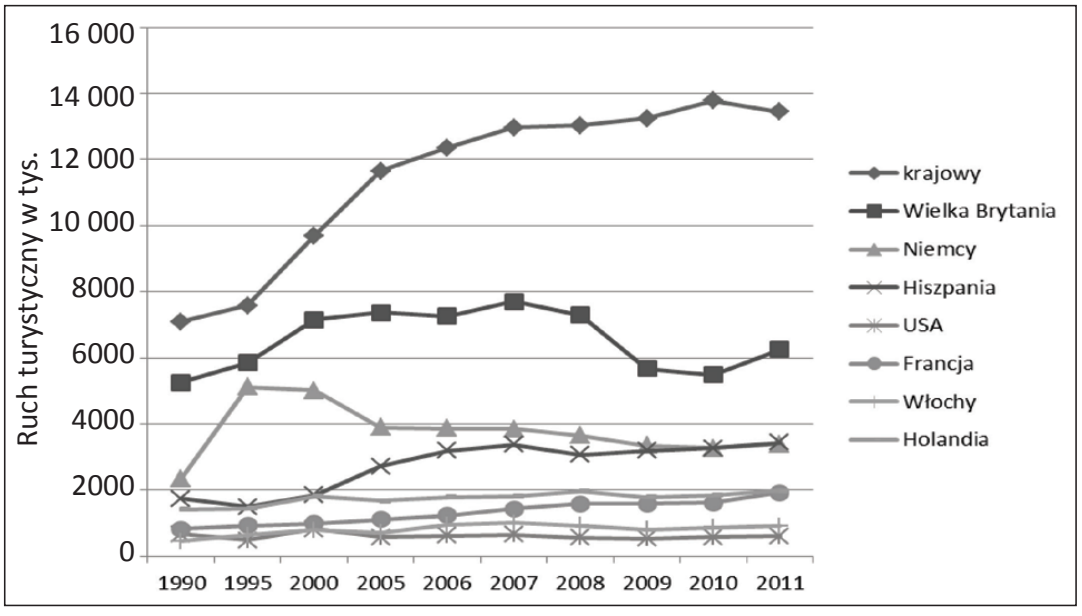

Ryc. 1. Wielkość krajowego i zagranicznego ruchu turystycznego w Portugalii

Źródło: Anuário Estatístico de Portugal 2011, Instituto Nacional de Estatística, IP

Przez zwiększoną liczbę turystów krajowych Portugalia obroniła się przed ogólną tendencją spadku wielkości ruchu turystycznego spowodowaną kryzysem ekonomicznym. Fakt ten potwierdza konieczność przygotowywania atrakcyjnej oferty turystycznej nie tylko dla turysty zagranicznego, ale przede wszystkim dla klientów krajowych.

\section{AlgarVE JAKO REGION TURYSTYCZNY}

Algarve jest najbardziej na południe wysuniętym regionem Portugalii (ryc. 2), stanowiącym płaskowyż o wysokości ok. 500 m n.p.m. Osłonięty od północy pasmami górskimi, znajdując się pod wpływem ciepłych mas powietrza z pobliskiej Afryki Północnej, ma 
najkorzystniejsze warunki dla rozwoju turystyki wypoczynkowej. Panuje tu łagodny klimat podzwrotnikowy. Temperatury latem w ciągu dnia wynoszą przeciętnie od 22 do $30^{\circ} \mathrm{C}$, w zimie wahają się od 15 do $20^{\circ} \mathrm{C}$. Deszcz w okresie wakacyjnym jest prawdziwą rzadkością.

Wybrzeże Algarve to najpiękniejszy odcinek portugalskiego wybrzeża. Długość linii brzegowej wynosi $207 \mathrm{~km}$, z czego $155 \mathrm{~km}$ obejmuje południowe wybrzeże, natomiast $52 \mathrm{~km}$ to wybrzeże zachodnie Algarve. Od Przylądka Św. Wincentego do miasta Faro jest ono niezwykle malownicze, ze skalistymi klifami, półwyspami i wyspami oraz małymi piaszczystymi zatokami. Na wschód od Faro jest ono niskie, piaszczyste, o krajobrazie lagunowym i wydmowym. 70\% obszaru wybrzeża Algarve to tereny objęte różnymi formami ochrony przyrody (Calvo, Tzschaschel, 1998). Łącznie na południowym wybrzeżu jest ponad 100 piaszczystych, szerokich plaż, przerywanych poszarpanymi, stromymi skałami i grotami. Szczególnie atrakcyjne miejsca dla plażowiczów położone są w kurortach Albufeira, Vilamoura i Alvor, a za najpiękniejszą część wybrzeża uchodzi Ponta da Piedade w Lagos.
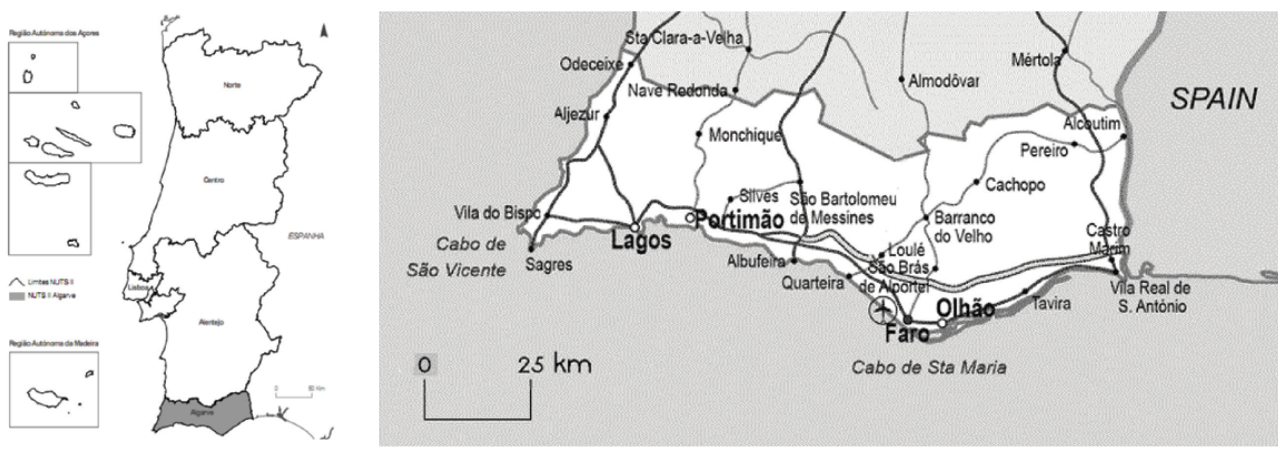

Ryc. 2. Położenie Algarve

Źródło: opracowanie własne na podstawie Anuário Estatístico de Portugal 2011, Instituto Nacional de Estatística, IP, http://www.101 traveldestinations.com

Podobnie jak całe południowe wybrzeże Europy, również wybrzeże Algarve było miejscem lokowania kapitału w inwestycje hotelowe, luksusowe apartamenty, domy wypoczynkowe i całą infrastrukturę turystyczno-sportową (Bajgier-Kowalska, Rettinger, 2011). Region ten posiada aż $60 \%$ udziału w ofercie turystycznej całego kraju, wyprzedzając Maderę i Lizbonę. Turystyka międzynarodowa stała się główną gałęzią miejscowej gospodarki, zastąpiwszy rolnictwo i rybołówstwo. Stolicą regionu Algarve i dystryktu o tej samej nazwie jest od 1756 roku Faro, miasto położone przy ujściu rzeki Formosa do Oceanu Atlantyckiego (ryc. 2), zwane bramą do Algarve. Historycznie Faro było ważnym centrum handlowym i administracyjnym, jednak w ciągu ostatnich 30 lat miasto przeistoczyło się w centrum turystyczne i kąpielisko regionu oraz jego najważniejszy ośrodek komunikacyjny. Jest to jednocześnie ważny ośrodek uniwersytecki kraju oraz duży port oceaniczny z przepięknym zabytkowym centrum. 
Miasta Algarve zachowały ślady ich arabskiej przeszłości i tradycyjnej architektury. Region stał się popularny wśród turystów od lat 60. ubiegłego wieku, ze względu na jego reputację jako ekskluzywnej alternatywy dla wybrzeży Morza Śródziemnego. Sprzyjający klimat, malowniczy krajobraz, piasek i ciepłe morze sprawiają, że jest to główny region turystyki wypoczynkowej w Portugalii (Correia, Crouch, 2004), miejsce drugich domów dla Brytyjczyków i innych mieszkańców północnej Europy (WTTC, 2003), a także wielu sławnych ludzi z całego świata (m.in. Madonna, Nigel Mansel, Cristiano Ronaldo, Jose Mourinho). Ponadto od dawna jest ulubionym miejscem dla emerytów (Petrova i in., 2009).

Szybki wzrost sektora turystycznego w połowie 1960 roku doprowadził do rozwoju miast i infrastruktury wspierającej, generowania wysokich przychodów i wzrostu gospodarczego w regionie, a także modernizacji i tworzenia infrastruktury turystycznej (Martins, 2010). Zmiany przeznaczenia gruntów miały swoje konsekwencje dla przybrzeżnych terenów Algarve, istniejących ekosystemów i dziedzictwa regionu (Vaz, Nijkamp, 2009), w wielu miejscach doprowadziły do degradacji wybrzeża i utraty naturalnych siedlisk (Nobre, 2009). Od 1990 do 2006 roku nastąpiło podwojenie wielkości obszaru zurbanizowanego (Vaz i in., 2012). Jest to szczególnie zauważalne w okolicach głównych miast Algarve, takich jak Portimao, Albufeira i Faro. W przeciwieństwie do tego, wnętrze regionu zarejestrowało tylko nieznaczny wzrost urbanizacji. Obserwuje się ciągły spadek udziału gruntów ornych z 44,55\% w 1990 roku do 40,06\% w 2006 roku, natomiast zwięszenie terenów leśnych, co jest efektem porzucania rolnictwa i przenoszenia się ludności do miast (Vaz i in., 2012). Ponad 65\% ludności mieszka w ośrodkach miejskich wzdłuż wybrzeża, głównie w Albufeirze, Faro i Olhao (Final Report..., 1999). Liczba stałych mieszkańców w regionie Algarve to około 400 tys. (średnia gęstość zaludnienia - 80 mieszkańców na km²) i charakteryzuje się stałym wzrostem.

Gospodarka Algarve jest silnie uzależniona od turystyki i usług, które dostarczają 2/3 cakowitego PKB regionu i 60\% całkowitego zatrudnienia (Petrova i in., 2009). W ostatniej dekadzie na skutek recesji gospodarczej nastąpił spadek ruchu turystycznego w Algarve i wpływów z turystyki. Władze regionu podjęły kluczowe decyzje dotyczące programu regionalnego rozwoju. Jednym z głównych priorytetów jest dywersyfikacja oferty turystycznej i rozwój nowych form turystyki, takich jak np. ekoturystyka czy turystyka zrównoważona (Vaz i in. 2012). Występujące rozległe obszary podmokłe, z naturalnymi siedliskami we wschodniej części regionu, objęte ochroną prawną, oraz naturalny krajobraz i duże powierzchnie leśne w środku prowincji dają szerokie możliwości rozwoju tych form turystyki (Bajgier-Kowalska, Rettinger, 2011).

\section{DYWERSYFIKACJA PRODUKTU TURYSTYCZNEGO JAKO ELEMENT BUDUJĄCY} PRZEWAGĘ KONKURENCYJNĄ REGIONU

Procesy globalizacyjne przyczyniły się do przejścia w myśleniu o rozwoju z poziomu krajowego na ogólnoświatowy, a jednocześnie wzmocniły znaczenie działań podejmowanych na poziomie regionalnym, a także lokalnym. W związku z tym we współczesnych 
koncepcjach rozwoju regionalnego dominują podejścia opierające się na zasobach wewnętrznych, szczególnie tych niepowtarzalnych i charakterystycznych jedynie dla tej konkretnej jednostki terytorialnej (Chądzyński i in., 2012). Ważnym zatem problemem jest uaktywnienie mechanizmów rozwojowych opartych na potencjale endogenicznym. W czasach kryzysu gospodarczego szukanie dróg poprawy sytuacji poprzez nowe inwestycje nie jest konieczne. Dobrym rozwiązaniem jest racjonalne, innowacyjne wykorzystanie istniejących zasobów lokalnych, a dobrze zarządzana turystyka może stać się sposobem na zachowanie i ochronę dziedzictwa przyrodniczego, kulturowego i historycznego oraz jego promocję. Elementy dziedzictwa stają się z jednej strony atrakcjami, wokół których tworzy się unikatowe produkty turystyczne, z drugiej zaś - pewnego rodzaju wyróżnikami danego miejsca czy regionu (Zdon-Korzeniowska, 2009).

W związku z tym szansą na rozwój turystyki w poszczególnych ośrodkach jest tworzenie regionalnych produktów turystycznych opartych na zasobach lokalnych. Produkt turystyczny jest to zbiór użyteczności związanych z podróżami turystycznymi, czyli dostępne na rynku dobra i usługi turystyczne umożliwiające ich planowanie, odbywanie, przeżywanie oraz gromadzenie doświadczeń z nimi związanych (Kaczmarek i in., 2010). Zatem ma on charakter złożony i jest różnorodny, a elementami różnicującymi mogą być właściwości nadawane przez poszczególne regiony.

Szeroko rozumiany produkt turystyczny oznacza więcej niż tylko prostą sumę walorów turystycznych oraz infrastruktury turystycznej i paraturystycznej, ponieważ na całkowite przeżycia turysty będą się składać także takie elementy, jak sposób świadczenia usług, warunki rozwoju gospodarczego obszaru, atrybuty estetyczno-emocjonalne, społeczne, organizacyjne i inne. Złożoność produktu turystycznego (obejmującego wszystkie walory, urządzenia i usługi, z których korzystają turyści) rzutuje na istotną cechę podaży turystycznej, czyli jej komplementarność. Decyduje ona o naturalnej konieczności współdziałania różnych podmiotów (w tym przedsiębiorstw turystycznych) w tworzeniu szeroko rozumianego produktu turystycznego, a tym samym kształtuje skomplikowany układ podmiotowy gospodarki turystycznej (Kachniewska, 2009).

Jednym z możliwych kierunków ograniczenia skutków światowego kryzysu gospodarczego, przejawiającego się m.in. spadkiem wielkości ruchu turystycznego, jest dywersyfikacja produktu turystycznego w oparciu o istniejący potencjał, który może przyczynić się do zdobycia nowych klientów. Według Goodalla (Goodall, 1992) dywersyfikacja produktu powinna być procesem ciągłym, zapewniającym regionowi dużą atrakcyjność na rynku turystycznym. Jednak sukces takiej strategii może być kwestionowany, ponieważ każda nowa inicjatywa jest szybko kopiowana przez konkurentów. Butler (Butter, 1980) już dawno stwierdził, że atrakcje są rzadko ponadczasowe i ostatecznie tracą konkurencyjność. Aby przedłużyć cykl rozwoju danego regionu i wzmocnić jego konkurencyjność, konieczne jest ciągłe tworzenie całkowicie nowych produktów turystycznych, zwłaszcza że czas ich realizacji jest niekiedy bardzo długi.

Jedną z możliwości dywersyfikacji regionalnego produktu turystycznego dla obszarów nadmorskich jest wprowadzenie elementów turystyki aktywnej. Aktualnie jest to dynamicznie rozwijająca się forma ruchu turystycznego, na którą występuje bardzo duże zapotrzebowanie ze strony turystów ,zmęczonych” biernym odpoczynkiem. Algarve było od dawna 
postrzegane przede wszystkim jako region turystyki wypoczynkowej, ale w latach 60. rozpoczął się proces uzupełniania profilu turystycznego o budowę pól golfowych. To tutaj w 1966 roku powstało pierwsze w kraju pole golfowe. Pięcio-, a nawet sześciogwiazdkowe hotele i prywatne wille położone między luksusowymi polami golfowymi oraz malownicze plaże stanowią idealne środowisko do rozwoju turystyki dla ludzi bogatych (Correia, Kozak, 2012). Aktualnie Portugalia dysponuje ok. 100 profesjonalnymi polami golfowymi (łącznie z polami położonymi na Maderze i na Azorach). Ale pierwsze miejsce zajmuje region Algarve, który jest jednym z najważniejszych kierunków golfowych na świecie. W ciągu roku na tutejszych polach rozgrywa się ok. miliona rund, a liczba fanów tego sportu rośnie o $7 \%$ rocznie.

Łagodny klimat i rekordowa liczba słonecznych dni w roku umożliwiają uprawianie tej dyscypliny przez cały rok, co czyni ten region niezwykle konkurencyjnym. Pola golfowe położone są wśród naturalnych krajobrazów - lasów sosnowych, jezior, plaż z białym piaskiem i wysokich klifów oraz ekskluzywnych kurortów, tętniących życiem we dnie i w nocy. Odbywa się tu wiele znaczących imprez związanych z golfem, jak np. jeden z najważniejszych turniejów golfowych Masters czy targi Portugal Golf Show, w których biorą udział firmy z całego świata. Pola golfowe w Algarve zostały zaprojektowane przez takie sławy, jak sir Henry Otton, Rocky Roquemore czy Arnold Palmer. Stanowią one prawdziwe wyzwanie dla graczy na różnym poziomie zaawansowania.

Takie pola jak San Lorenzo lub Old Course w Vilamourze plasują się wśród najlepszych tego typu obiektów Europy. Wg rankingu prestiżowego magazynu „Golf World” 10 pól golfowych z Algarve znalazło się wśród 100 najlepszych w Europie. Stowarzyszenie IAGTO (International Association of Golf Tour Operators) przyznało Algarve tytuł Established Golf Destination of the Year 2006 (IAGTO, 2013). Eksperci podkreślają, że golf to sport uchodzący za prestiżowy i ekskluzywny. Uprawiający go zamożni turyści są bardzo cenną dla Portugalii grupą klientów. Według S. Hudson i L. Hudson (Hudson, Hudson, 2010) po świecie podróżuje ok. $50 \mathrm{mln}$ turystów golfowych.

Przez turystów portugalskich Algarve jest uznawane za symbol snobizmu i prestiżu. Badania dotyczące zachowań turystów golfowych w tym regionie wskazują, że turyści (gracze), wybierając to miejsce, nie kierują się motywacją związaną ze sportem, a raczej z jego społecznym aspektem. Ludzie chcą grać tam, gdzie robią to znani i sławni turyści (Correia i in., 2007). To właśnie snobistyczne motywacje kierują turystów do Algarve, do pobytu w najdroższych hotelach i korzystania z wyszukanych doświadczeń (Correia, Kozak, 2012). Podobnie prestiż, status społeczny i rozgłos stanowi istotny warunek wpływający na ich decyzje do odwiedzenia Ameryki Łacińskiej (Correia i in., 2007). Spośród 3000 turystów krajowych przebywających w 2009 roku w Algarve 74,8\% wybrało ten region ze względu na słońce, piasek i prestiż tego miejsca, a 24,2\% - na golf. 42,7\% turystów korzystało z najdroższych pięciogwiazdkowych hoteli, w których spędzali średnio 10,4 nocy. Ok. 52\% stanowili turyści w wieku 31-50 lat, z wyższym wykształceniem, pochodzący ze średniej klasy społecznej (Correia, Kozak, 2012).

Algarve jest również postrzegane jako miejsce modne na wakacje oraz sposób na osiągnięcie pewnego statusu społecznego. Przy wyborze miejsc docelowych motywy 
snobistyczne ludzi są przeciwieństwem mody na dany region. Leibenstein (Leibenstein, 1950) twierdzi, że podejście snobistyczne reprezentuje pragnienie ludzi do wyjątkowości, odmienności i dystansowania się od „wspólnego stada”. W turystyce skrajne podejście snobistyczne wyraża się wyborem najbardziej egzotycznych i słynnych miejsc docelowych, które są ekskluzywne i niezwykłe (Lee, Hwang, 2011).

Warunki naturalne południowej części Portugalii predysponują ten obszar do rozwoju turystyki aktywnej związanej z morzem. Klimat i doskonałe warunki oceaniczne, z wysokimi falami, przyciągają miłośników surfingu, windsurfingu i kitesurfingu, tak z Europy, jak i z całego świata. Z każdym rokiem przybywa tu szkół oraz ośrodków turystyki aktywnej. W celu przyciągnięcia jak największej liczby zagranicznych surferów Portugalska Organizacja Turystyczna prowadzi liczne akcje. Jedną z nich był zwrot kosztów powrotu do domu zagranicznym turystom, którzy przyjechali tu, aby uprawiać surfing, lecz nie znaleźli odpowiednio wysokich fal. Akcja, która prowadzona była w drugiej połowie 2012 do stycznia 2013 roku, dotyczyła amatorów surfingu, którzy przez trzy kolejne dni pobytu w Portugalii nie znaleźli dogodnych warunków do uprawiania tej dyscypliny sportu (fale powyżej $0,5 \mathrm{~m}$ ). Promocją objętych było blisko 30 najczęściej uczęszczanych przez surferów plaż. Organizowane w 2011 i 2012 roku mistrzostwa świata w tej dyscyplinie sportu przyciągnęły do Portugalii tysiące obcokrajowców. Ogromną reklamą dla Portugalii, jako kraju wysokich fal, był pobity rekord świata w Nazare, na środkowym wybrzeżu. Amerykanin Garrett McNamara utrzymał się na fali o wysokości 30 metrów (Money.pl, 2013).

Nowym elementem składowym produktu turystycznego Algarve są sporty samochodowe. Bardzo dobra wewnętrzna dostępność komunikacyjna, rozpatrywana w kontekście jakości i liczby dróg kołowych, może być atrakcją turystyczną, zwłaszcza gdy drogi te są miejscem rywalizacji w wyścigach samochodowych. Odbywają się one pomiędzy Portimao i Lagos. Ta innowacja produktowa przyciąga nie tylko uczestników wyścigów, ale również obserwatorów.

\section{SPECJALIZACJA PRODUKTOWA W OBRĘBIE WYBRANYCH SEGMENTÓW RYNKU TURYSTYCZNEGO JAKO ELEMENT POLITYKI TURYSTYCZNEJ ALGARVE}

Jednym ze sposobów przeciwdziałania sytuacjom kryzysowym w turystyce jest poszukiwanie nowych klientów poprzez tworzenie oferty turystycznej dla konkretnych grup społecznych, zawodowych czy też narodowościowych. Dotyczy to między innymi seniorów. Dlatego też Portugalska Agencja ds. Promocji Turystyki (Turismo de Portugal), w partnerstwie z Portugalskim Stowarzyszeniem Domów Wypoczynkowych (Associação Portuguesa de Resorts) i przy wsparciu portugalskiego rządu, zainicjowała w styczniu 2013 roku program promocji sektora turystyki rezydencjalnej „Living in Portugal”. Stawia on za swój główny cel sprzedaż 6-10 tys. nieruchomości mieszkalnych.

Program ten, pod roboczym hasłem Emerytura w słońcu, portugalskie Ministerstwo Gospodarki zaprezentowało już pod koniec 2011 roku. Jego najważniejszym zadaniem jest przyciągnięcie do tego kraju emerytów z bogatych państw Europy Północnej. Zainicjowana 
w Wielkiej Brytanii akcja reklamowa ma trwać do końca 2014 roku. Będzie ona prezentowana w Niemczech, Szwecji, Holandii i Francji, czyli krajach, których obywatele najczęściej wybierają Portugalię na drugie miejsce swojego zamieszkania. Program ten, dzięki ulgom podatkowym, może zachęcić nawet 100 tys. zagranicznych turystów do zamieszkiwania w Portugalii przez co najmniej 6 miesięcy w roku (Rząd Portugalii..., 2013).

Wdrażany przez rząd program poszukiwania zagranicznych rezydentów adresowany jest również do obywateli państw spoza Unii Europejskiej, zwłaszcza Rosji. Od 1 stycznia 2012 roku w Portugalii obowiązują dla nich łatwiejsze zasady nabywania prawa do stałego pobytu. Mogą otrzymać je biznesmeni, którzy zainwestują ponad $1 \mathrm{mln}$ euro, pomogą stworzyć 30 miejsc pracy lub nabędą nieruchomość o minimalnej wartości 500 tys. euro. $\mathrm{Z}$ danych resortu gospodarki w Lizbonie wynika, że w ciągu roku w europejskich krajach basenu Morza Śródziemnego zagraniczni turyści nabywają łącznie około 100 tys. apartamentów. W 40\% przypadków rezydenci obcokrajowcy decydują się na Hiszpanię, w 25\% - na Francję, 15\% wybiera Włochy, a 4\% - Portugalię.

Portugalski rząd do 2015 roku zamierza wydać 828 mln euro na rozwój programu turystyki rezydencyjnej. Na terenie Portugalii żyje około 150 tys. obywateli zagranicznych, którzy wybrali ją na drugi kraj zamieszkania. Dominują wśród nich emerytowani Brytyjczycy, Niemcy oraz Holendrzy (Rząd Portugalii..., 2013). W ostatnich latach również rosyjskie elity wykupują nieruchomości w Portugalii. Głównym celem ich inwestycji są luksusowe apartamenty z widokiem na ocean za $1 \mathrm{mln}$ euro. Tylko w minionym roku Rosjanie nabyli w Portugalii ponad 500 nieruchomości, głównie domów na wybrzeżu. Najchętniej przez nich kupowanymi obiektami są budynki na terenie aglomeracji lizbońskiej oraz w regionie Algarve. W ciągu ostatnich 5 lat rosyjskie inwestycje w portugalskie nieruchomości zwiększyły się aż o 1000\% i, jak przewidują eksperci, w najbliższych latach będą one rosnąć w związku ze zmianą przepisów o tytule stałego pobytu.

Podjęto również działania zminimalizowania negatywnego wpływu sezonowości na turystykę rezydencjalną, m.in. przez poprawę oferty linii lotniczych w zimie, zwłaszcza do Algarve. Poza elementem sprzedaży, program przewiduje również utworzenie portalu informacyjnego www.livingportugal.com, który będzie służył jako narzędzie do udzielania wyjaśnień na temat różnych aspektów dotyczących warunków życia w Portugalii oraz niezbędnych procedur przy nabywaniu nieruchomości rezydencjalnych, począwszy od spraw podatkowych, a skończywszy na biurokratycznych. Portal ten będzie posiadał ponadto listę nieruchomości wystawionych na sprzedaż i będzie redagowany w kilku językach. Podczas prezentacji kampanii „Living in Portugal” minister spraw wewnętrznych Miguel Macedo poinformował, że w 2012 roku ponad 20 tys. cudzoziemców uzyskało zezwolenie na pobyt w Portugalii, z czego większość stanowili obywatele z Wielkiej Brytanii, Hiszpanii, Holandii i Niemiec. Jak podaje system kontroli granicznej w Portugalii (PASSE, Processo Automático e Seguro de Saídas e Entradas), przetwarzający dane dotyczące wjazdów i wyjazdów z terenu tego kraju, w 2012 roku zarejestrowano 5,6 mln osób, z czego 1,1 mln miało ponad 50 lat (Rząd Portugalii..., 2013).

Poszukiwanie nowych grup odbiorców portugalskiej oferty turystycznej opiera się także na turystach zainteresowanych krótkookresowym odpoczynkiem poza sezonem 
turystycznym. Portugalia poszła w ślady Hiszpanii, w której od października 2009 do kwietnia 2010 roku był realizowany program „Turystyka seniorów w Europie” (Europe Senior Tourism), zwany również „Calypso”, którego celem było zachęcenie starszych osób do wyjazdów turystycznych do Hiszpanii poza sezonem wakacyjnym. Zachętą do takich wyjazdów było dofinansowanie przez Unię Europejską pakietów turystycznych dla każdego obywatela Unii w wieku 55-75 lat oraz osoby mu towarzyszącej (Europe..., 2013). Mieszkańcy Europy w takim wieku stanowią ponad $20 \%$ europejskiego rynku turystycznego.

W latach 2005-2010 liczba wakacyjnych wyjazdów wśród Europejczyków w wieku powyżej 55 lat wzrosła o 17\%. Ta grupa wiekowa w całości stanowi ponad 1/4 (27\%) wszystkich podróżujących za granicę. Odpowiada to liczbie $78 \mathrm{mln}$ wakacyjnych wycieczek rocznie (Emerytura..., 2013). Według analizy Eurostatu europejskiej turystyce udało się przetrwać kryzys głównie dzięki rosnącej aktywności osób starszych. W 2011 roku, w porównaniu z rokiem 2006, liczba turystów zmalała we wszystkich grupach wiekowych, z wyjątkiem tej obejmującej osoby powyżej 65 roku życia, która zanotowała wzrost aż o 10\%. W grupie tej wzrosła też liczba podróży (o 29\%), liczba noclegów podczas wyjazdów (o 23\%) i wydatki na turystykę (o 33\%). Osoby starsze, nieobawiające się utraty pracy i mające stabilne źródło dochodów w postaci emerytury czy renty, relatywnie najmniej odczuwają spowolnienie gospodarcze, które dotyka Europę i świat od kilku lat. Obniżka cen usług turystycznych spowodowanych kryzysem gospodarczym, zwłaszcza na południu Europy, stwarza dla turystów seniorów znakomitą okazję do podróżowania (Emerytura..., 2013).

\section{Podsumowanie}

W dobie gospodarki opartej na wiedzy procesy innowacyjne wykorzystują nie tylko wewnętrzne zasoby organizacji, ale także wymagają współpracy i kooperacji różnorodnych organizacji i instytucji. Ważnym elementem jest wzmacnianie pozycji konkurencyjnej regionu oraz podmiotów w nim działających. Polityka regionalna państwa powinna zmierzać do przygotowywania scenariuszy działań przeciwdziałających zjawiskom kryzysowym. Jedynie działania systemowe obejmujące swoim zasięgiem większe jednostki terytorialne mogą przynieść oczekiwane efekty.

Bardzo ważnym zagadnieniem jest równoważenie udziału zagranicznego ruchu turystycznego ruchem krajowym. Oczywiście, jest to możliwe w krajach stosunkowo dobrze rozwiniętych gospodarczo. Rynek lokalny jest pewnego rodzaju ostoją dla firm działających w branży turystycznej, gwarantem stabilności i trwałości, w odróżnieniu od rynku globalnego - pełnego zmian, niepewności i destabilizacji. Dlatego w polityce rozwojowej nie można zapominać o turyście krajowym.

Południowa część Portugalii - Algarve jest jednym z najciekawszych regionów turystycznych Półwyspu Iberyjskiego, promowanym jako prestiżowy produkt. To idealne miejsce do rozwijania poczucia wyższego statusu społecznego, czego szuka znaczna grupa turystów. Zdolność przyciągania turystów, zarówno krajowych, jak i zagranicznych, jest duża, 
ale również ograniczona. Stąd rola decydentów, aby wzbogacić produkt turystyczny Algarve w celu zdobycia turysty. Działaniem zapobiegawczym jest nie tylko dywersyfikacja produktu, lecz także poszukiwanie nowych segmentów rynku turystycznego.

\section{Literatura \\ References}

Algieri, B. (2006). International tourism specialization of small countries. International Journal of Tourism Research, 8, 1-12.

Anuário Estatístico de Portugal 2011, 2012. Instituto Nacional de Estatística IP (2013, 4 września). Pozyskano z http://www.ine.pt/

Archer, B. (1995). Importance of tourism for the economy of Bermuda. Annals of Tourism Research, 22(4), 918-930.

Bajgier-Kowalska, M., Rettinger, R. (2011). Uwarunkowania międzynarodowej konkurencyjności regionu turystycznego Algarve w Portugalii. Państwo i Społeczeństwo, XI, 1, $207-222$.

Belisle, F., Hoy, D. (1980). The perceived impact of tourism by residents. Annals of Tourism Research, 8, 83-97.

Brida, J.G., Risso, W.A. (2009). Tourism as a factor of long-run economic growth: An empirical analysis for Chile. European Journal of Tourism Research, 2(2), 178-185.

Brida, J.G., Punzo, L.F., Risso, W.A. (2011). Tourism as a factor of growth: The case of Brazil. Tourism Economics, 17(6), 1375-1386.

Bryden, J.M. (1973). Tourism and development: A case study of the commonwealth Caribbean. Cambridge: Cambridge University Press.

Butler, R., (1980). The Concept of a Tourist Area Cycle of Evolution: Implications for Management of Resources. Canadian Geographer, 24, 5-12.

Calvo, G., Tzschaschel, S. (1998). Portugalia. Warszawa: Geocenter.

Chądzyński, J., Nowakowska, A., Przygodzki, Z. (2012). Region i jego rozwój w warunkach globalizacji. Warszawa: Wydawnictwo CeDeWu.

Correia, A., Barros, C., Silvestre, L. (2007). Golf tourism repeat choice behavior in the Algarve: A mixed logit approach. Tourism Economics, 13(1), 111-127.

Correia, A., Crouch, G.I. (2004). A study of tourist decision processes: Algarve Portugal. W: G.I. Crouch, R.R. Perdue, H.J.P. Timmermans, M. Uysal (red.). Consumer psychology of tourism, hospitality and leisure. UK: Oxfordshire, Cabi Publishing.

Correia, A., Kozak, M. (2012). Exploring prestige and status on domestic destinations: the case of Algarve. Annals of Tourism Research, 39(4), 1951-1967.

Correia, A., Santos, C., Barros, C. (2007). Tourism in Latin America: A choice analysis. Annals of Tourism Research, 34(3), 610-629.

Cortés-Jiménez, I., Nowak, J., Sahli, M. (2011). Mass beach tourism and economic growth: Lessons from Tunisia. Tourism Economics, 17(3), 531-547.

Davis, D., Allen, J., Consenza, R.M. (1988). Segmenting local residents by their attitudes, interests, and opinions toward tourism. Journal of Travel Research, 27(2), 2-8.

Dritsakis, N. (2012). Tourism development and economic growth in seven Mediterranean countries: A panel data approach. Tourism Economics, 18(4), 801-816.

Durbarry, R. (2002). The economic contribution of tourism in Mauritius. Annals of Tourism Research, 29(3), 862-865.

Ekanayake, E.M., Long, A.E. (2012). Tourism development and economic growth in developing countries. The International Journal of Business and Finance Research, 6(1), 51-63. 
Emerytura w słońcu - Portugalia chce przyciagnąć seniorów (2013, 12 listopada). Pozyskano z http:// travel-fan.pl/news/emerytura-w-sloncu-portugalia-chce-przyciagnac-seniorow/

Europe Senior Tourism. (2013, 10 września). Pozyskano z http://www.europeseniortourism.eu

Final Report, Murbandy: Change Algarve (1999). Contract Nr 14644-1998-12, Centro National de Informacao Geografica. Portugal.

Goodall, B. (1992). Coastal Resorts: Development and Redevelopment. Built Environment, 18, 5-11.

Gray, H.P. (1970). International arrivals: International trade. Lexington: D.C. Heath.

Heng, T.M., Low, L. (1990). The economic impact of tourism in Singapore. Annals of Tourism Research, 17(2), 46-69.

Hudson, S., Hudson, L. (2010). Golf Tourism. Woodeaton, Oxford: Goodfellow Publishers Limited.

IAGTO (2013, 22 października). Pozyskano z http://www.tuitam.pl/golf/algarvegolf.htm

Kachniewska, M. (2009). Uwarunkowania konkurencyjności przedsiębiorstwa turystycznego. Warszawa: SGH.

Kaczmarek, J., Stasiak, A., Włodarczyk, B. (2010). Produkt turystyczny. Warszawa: Polskie Wydawnictwo Ekonomiczne.

Kadir, N., Jusoff, K. (2010). The cointegration and causality tests for tourism and trade in Malaysia. International Research Journal of Finance and Economics, 2(1), 138-143.

Keintz, R.M. (1971). A study of the demand for international travel to and from the United States. The American Economist, 15(1), 137-138.

Khan, H., Seng, C., Cheong, W. (1990). Tourism multipliers effects on Singapore. Annals of Tourism Research, 17, 408-418.

Lee, J.H., Hwang, J. (2011). Luxury marketing: The influences of psychological and demographic characteristics on attitudes toward luxury restaurants. International Journal of Hospitality Management, 30(3), 658-669.

Leibenstein, H. (1950). Bandwagon, snob, and veblen effects in the theory of consumers' demand. Quarterly Journal of Economics, 64(May), 183-207.

Lionetti, S., Gonzalez, O. (2012). On the relationship between tourism and growth in Latin America. Tourism and Hospitality Research, 12(1), 15-24.

Martins, J.C. (2010). Urban growth and leisure metropolitan territories: Tourism in Algarve (Portugal) through National Road 125 (1960-2013). W: 8th European Urban \& Regional Studies Conference. Wiedeń: Vienna University of Economics and Business.

Money.pl (2013, 8 października). Pozyskano z http://www.money.pl

Narayan, P.K., Narayan, S., Prasad, A., Prasad, B.C. (2010). Tourism, and economic growth: A panel data analysis for Pacific Island countries. Tourism Economics, 16(1), 169-183.

Nobre, A. (2009). An ecological and economic assessment methodology for coastal ecosystem management. Environmental Management, 44, 185-204.

Pablo-Romero, M., Molina, J.A. (2013). Tourism and economic growth: A review of empirical literature. Tourism Management Perspectives, 8, $28-41$.

Petrova, L.O., Lavalle, C., Kasanko, M. (2009). Urban land use scenarios for a tourist region in Europe: Applying the MOLAND model to Algarve, Portugal. Landscape and Urban Planning, 92, 10-23.

Pola golfowe w Portugalii (2013, 22 października). Pozyskano z http://www.tuitam.pl/golf/algarvegolf.htm

Portugalia rekompensuje brak fal. Oddadza za bilet. (2013, 8 października). Pozyskano z http:// www.money.pl/gospodarka/turystyka/artykul/portugalia;rekompensuje;brak;fal;oddadza;za;bilet, $248,0,1182712 . \mathrm{html}$

Rząd Portugalii zamierza pobudzić rozwój turystyki rezydencjalnej (2013, 10 września). Pozyskano z http://www.lisbon.trade.gov.pl/pl/aktualnosci/article/a,34432.html

Santana-Gallego, M., Ledesma-Rodríguez, F., Pérez-Rodríguez, J. (2011). On the relationships between trade and tourism. W: F. Cerina, A. Markandya, M. McAleer (red.). The Economics of Sustainable Tourism, 6, 92-107. 
Vaz, E., Nijkamp, P. (2009). Historico-cultural sustainability and urban dynamics, in enhancing the city. W: G. Maciocco, S. Serrelli (red.). Urban and landscape perspectives, 155-177.

Vaz, E., Nijkamp, P., Painhoa, M., Caetano, M. (2012). A multi-scenario forecast of urban change: A study on urban growth in the Algarve. Landscape and Urban Planning, 104, 201-211.

World Travel and Tourism Council (WTTC) (2003). The Algarve, The Impact of Travel and Tourism on Jobs and the Economy. Pozyskano z http://www.wttc.org/

Zdon-Korzeniowska, M. (2009). Jak kształtować regionalne produkty turystyczne? Teoria i praktyka. Kraków: Wydawnictwo UJ.

Zdon-Korzeniowska, M., Rachwał T. (2011). Turystyka w warunkach światowego kryzysu gospodarczego. Prace Komisji Geografii Przemystu Polskiego Towarzystwa Geograficznego, 18, 116-127.

Malgorzata Bajgier-Kowalska, doktor, adiunkt, Krakowska Akademia im. Andrzeja Frycza Modrzewskiego, Wydział Prawa, Administracji i Stosunków Międzynarodowych, Katedra Turystyki Międzynarodowej i Geografii Społecznej

Zainteresowania naukowo-badawcze i tematyka publikacji koncentrują się wokół problemów geomorfologicznych oraz zagadnień z zakresu geografii regionalnej. W ostatnich latach badania autorki dotyczą problematyki rozwoju turystyki i rekreacji, głównie zagadnień uwarunkowań rozwoju i funkcjonowania regionów turystycznych na świecie, analizy przestrzennego zróżnicowania zagospodarowania turystycznego oraz wielkości ruchu turystycznego.

Małgorzata Bajgier-Kowalska, Ph.D. The academic and research interests of the author, as well as topics of her publications are concentrated around geomorphology and regional geography. In her research, the author also concentrates on the problem of tourism and recreation growth, especially on the question of development conditions and functioning of tourist regions in the world, including the analyses of spatial differentiation of tourist infrastructure, and size of tourism itself.

Renata Rettinger, doktor, adiunkt, Uniwersytet Pedagogiczny w Krakowie, Instytut Geografii, Zakład Turystyki i Badań Regionalnych

Autorka w swoich badaniach koncentruje się na problematyce rozwoju turystyki w regionie karaibskim. W problematyce badawczej przeważają tematy dotyczące wielkości i przestrzennego zróżnicowania zagospodarowania i ruchu turystycznego, a w szczególności kierunki rozwoju turystyki. W opracowaniach przewija się także tematyka enklaw turystycznych jako dominującej formy zagospodarowania turystycznego na Karaibach w kontekście rozwoju zrównoważonego i turystyki pro-poor.

Renata Rettinger, Ph.D. In her research, the author concentrates on the problems of tourism development in the Caribbean region. The dominating research topics are the size and spatial differentiation of tourist infrastructure and tourism volume itself together with the directions of the tourism development. The research topics also include the issue of tourist enclaves as a dominating form of tourist infrastructure in the Caribbean region in light of sustainable development and pro-poor tourism.

\section{Adres/address:}

Krakowska Akademia im. Andrzeja Frycza Modrzewskiego

Wydział Prawa, Administracji i Stosunków Międzynarodowych

Katedra Turystyki Międzynarodowej i Geografii Społecznej

ul. Gustawa Herlinga-Grudzińskiego 1, 30-705 Kraków, Polska

e-mail: malbajkow@interia.pl (Małgorzata Bajgier-Kowalska)

Uniwersytet Pedagogiczny w Krakowie

Instytut Geografii

Zakład Turystyki i Badań Regionalnych

ul. Podchorążych 2, 30-084 Kraków, Polska

e-mail: rettinger@onet.eu (Renata Rettinger) 